\title{
Building Information Modeling: Quality of life
}

\author{
Roshana Takim ${ }^{a}$, Mohd Harris ${ }^{b}$, Abdul Hadi Nawawi ${ }^{c}$ \\ a Centre of Construction Management Studies \\ ${ }^{b}$ Centre of Postgraduate Studies \\ c Centre of Estate Management Studies \\ Faculty of Architecture, Planning \& Surveying, Universiti Teknologi MARA, Malaysia \\ dr_roshana@salam.uitm.edu.my
}

\begin{abstract}
The adoption of Building Information Modeling (BIM) constitutes a paradigm shift in the architectural, engineering and construction (AEC) industry. Broader BIM adoption will transform construction processes to achieve greater efficiency to improve the quality of life (QOL) of construction stakeholders. This paper seeks to identify determinant factors and implementation gaps of BIM in the AEC industry. A case study was conducted through a preliminary workshop organised by CIDB among the five potential stakeholders from Malaysian public and private. Finally, the workshop suggested an 'affordable BIM concept' with 'pay-per-use or periodical license' method to be adopted for SMEs contractors.
\end{abstract}

Keywords: Building Information Modeling (BIM); BIM influencing model; construction; technology

eISSN: 2398-4279 @ 2016. The Authors. Published for AMER ABRA by e-International Publishing House, Ltd., UK.. This is an open access article under the CC BY-NC-ND license (http://creativecommons.org/licenses/by-ncnd/4.0/). Peer-review under responsibility of AMER (Association of Malaysian Environment-Behaviour Researchers), ABRA (Association of Behavioural Researchers on Asians) and cE-Bs (Centre for EnvironmentBehaviour Studies), Faculty of Architecture, Planning \& Surveying, Universiti Teknologi MARA, Malaysia.

https://doi.org/10.21834/ajqol.v1i1.30 


\subsection{Introduction}

Technology is changing and developing around the world at a rate and pace never experienced before. The contribution of new technology to economic growth can only be realized when and if the new technology is widely adopted and used. Adoption itself results from a series of individual decisions to begin using the new technology, decisions which are often the result of a comparison between the uncertain benefits of the new invention and the unknown costs of adopting it (Parente and Prescott, 1994). The AEC industry is often perceived as being slow in adopting technology and was claimed to cling on to old business models and processes for decades. Nevertheless, the AEC industry has several practical applications that facilitate the technology, outsourcing and exchange of information within the industry, the roles of technology adopted are important to sustain the quality of life (QOL) to mankind. For instance Computer Aided Design (CAD) or drafting is a technology widely used by the AEC industry. $C A D$ is a form of computer-aided building modulation that architects, engineers and contractors use to create and view two-and three-dimensional models. The AEC industry also uses BIM, a newer computerized modeling system that can create up to six-dimensional models; this software can substantially increase productivity in the AEC industry. Hence, the task of AEC industry is to be able to adopt and apply technologies to improve the quality and productivity of the industry (Hassan, 2012).

Much attention in the AEC industry today is focusing on BIM. CIDB (2013) defines BIM as a process supported by the technology of computer generated model used in collaboration to populate information and simulate the planning, design, construction and operation of a facility.

BIM is now being increasingly used as an emerging technology to assist in conceiving, designing, construction and operating the building in many countries (Wong et. al., 2009). It is recognized as a new management technology that provides an integrated solution to operate businesses while improving the client satisfaction to time, cost, safety, quality and functionality of construction projects. Meanwhile, there is a great diversity in ideas about definitions on QOL. Some perceive it as the environment we live, the house and the air we breathe, while others describe it as safety and security, health, wealth (employment), transport infrastructures, adequate building for housing, schooling and recreation (Mercer, 2007). In general, QOL is a subjective matter that involves a person's emotional state and personal life. To achieve any of the perceive QOL, adoption of new technology is inevitable.

This paper seeks to identify the key determinant factors and implementation gaps of BIM in the AEC industry. A Technology Acceptance Model (TAM) developed by Davis (1989) posits that human feelings, behavior and attitude are the triggers to begin adopting new technology. The study accesses the impact of perceiving usefulness and ease-of-use to the broader adoption of BIM, which will ultimately contribute to the improvement of QOL in the AEC industry. 


\subsection{Background}

One of the Malaysian government agenda in the 12 National Key Economic Areas (NKEAs) is to enhance business growth in the AEC industry (Pemandu, 2011). For this matter, the AEC organizations have aggressively embraced new technology to remain competitive in the current market (Alshawi et.al. 2010). BIM is one of the new emerging technologies to be deployed in the design, construction, and facility management in which a digital representation of the building process is being created to facilitate the exchange and interoperability of information in digital format. Despite the advantages derived from this paradigm, the local construction industry is reluctant to deploy the technology in its service delivery (Shuratman, 2012).

BIM has existed for over 20 years; it is only over the last few years that the construction industry is aware that BIM promises to make the industry much more streamlined and efficient (Arayici, et. al., 2012). BIM applications have grown tremendously, from a tool to design in three dimensions and use of components, to a tool that is used for model analysis, clash detection, product selection, and whole project conceptualization (Weygant, 2011). BIM is now being increasingly used as an emerging technology to assist in conceiving, designing, construction and operating the building in many countries (Wong et.al. 2009). It is providing itself as a very powerful tool that allows users to create a visual simulation of a project and provides a virtual prototype of a building before construction. However, BIM requires specialized training because of the complexity of the processes.

Despite the industry's awareness of the potential of BIM, construction organisations are yet to utilise it aggressively. According to Khosrowshahi and Arayici (2012), the UK construction sector is facing slow progressive changes in the BIM implementation. The probable reasons could be the difficulty to implement BIM, adoption could incur higher additional project cost, require a comprehensive training, and the majority of the designers are still familiar in using AutoCAD in their design services instead of BIM.

\subsection{Methodology}

The study starts with literature search which reviews the determining factors in the adoption and implementation of BIM in the AEC industry. Further research has been carried out through a workshop by the Construction Industry Development Board (CIDB) to investigate the determining factors and implementation gaps of BIM movement within the five potential stakeholders: Public Private Partnership (PPP) Unit (UKAS), JARING, eMOST/ UMP, Greenwave Synergy (GWS) and CIDB eConstruct (EC) of the AEC industries in Malaysia. The data were processed using content analysis techniques. 


\subsection{Determinant factors of technology acceptance}

\subsubsection{Categories of technology adoption}

The introduction of new technology usually begins before an official decision made by the organisations. Most local and international organisations decide to adopt technology based on the benefits or competitive advantage that they will gain through the push factors such as regulations, policy and industry standards (Abukhzam and Lee, 2010). Similarly, in Malaysia, the AEC industry decides to regulate the technology implementation based on economic demand, advantages and global competitiveness (Parente and Prescott, 1994; Hasan, 2012). For the technology to be adopted conversantly, training and support in the use of the technology are inevitable due to the complexity of its processes (Suebin and Gerdsri, 2009). In this regard, technology adoption could be categorised into two levels: national and organisational/individual levels. At the national level, the passage means the decision at the ministry to mandate or regulate the use of technology throughout the whole nation. This will result in policy making and development of national standards and enforcement acts. The organisational level is referring to the decision made by the top management of the organisations based on the push factors, or the competitive needs to be a champion in the respective area (Teng and Nelson, 1996). The organisational level could also include the individual's acceptance and motivation to accept changes and the ability to learn new ideas. This motivation and ability to learn are hugely dependent on the ease-ofuse of the technology and its usefulness to each. Without the acceptance from the individuals, the organisation will not obtain any benefits from investing in new technology (Suebin and Gerdsri, 2009).

\subsubsection{Factors influencing the choice to adopt}

When people are presented with new technology in the market, some factors influence their decisions on how and when to use the technology (Majid et.al, 2011). These decisions are related to their perceptions of the new technology through social communication but with fearful of changes (Suebin and Gerdsri, 2009). The use and adoption of new technology is a process that begins with awareness of the technology and progresses through a series of stages that end in appropriate and effective usages. According to BTC (2005), factors influencing the choice to adopt technology could be in five stages. These are awareness, assessment, acceptance, learning and usage. Awareness implies the knowledge gained by potential users through one's perceptions or by means of information about the technology, its benefits, and plan to investigate further; assessment is the potential users' evaluation of the usefulness, usability, difficulty in adopting the technology; acceptance means potential users' decision to acquire and use the technology, or decide not to adopt; learning is when users' develop the skills and knowledge to use the technology effectively; and finally, usage is when the users demonstrate the practical use of the technology and conform of the adoption. Figure 1 shows TAM theory which employs the 
perception towards technology usefulness and ease-of-use as determinant factors to technology adoption (Davis, 1989).TAM theory starts with the exertion of external factors or external variables such as the stimulus from political influence, regulation and implementation process as the push factors. While the combination of perceived usefulness and perceived ease-of-use will form the attitude and intention to use before full acceptance and actual use of any new system or technology in the industry. Perceived usefulness is defined as the degree to which an adopter believes the new technology would improve or enhance job performance, meanwhile perceived ease-of-use refers to the users perception of the minimum effort required for the use of new technology. Venkatesh and Davis (2001) developed the extended model of TAM called TAM2 by including the social influence and cognitive instrumental processes into the equation. TAM3 is later being established by Venkatesh (2012) as an extended version of TAM2. However, the models are consistent with the basic TAM theory which defines perceived usefulness and perceived ease-of-use as key predictors of technology acceptance within the AEC industry.

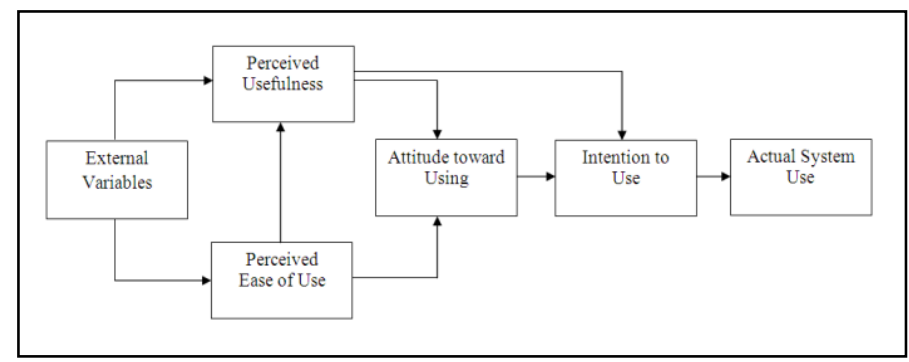

Figure 1: Technology Acceptance (TAM)

(Source: Davis, 1989)

\subsubsection{Mediating factors to technology implementation}

Studies have demonstrated that the issue of technology adoption is very complex. Upon the analysis to begin accepting and the decision to adopt, the readiness of the organisations in respect to the product, process, and people is sought (Gu and London, 2010). Product refers to the capability and complexity of the selected system to fulfil the users' requirements; process means the necessity to revisit current work processes that require changes or otherwise; while people refers to users and top management awareness, involvement, sufficient training and adequate support. These are mediating factors to technology implementation within the organisations (Khosrowshahi and Arayici, 2012). Figure 2 illustrates the general process flow of new technology adoption and implementation in the AEC industry.

Upon the incursion of technology into the nation, the benefits, competitive-advantage and championship will be evaluated. In the event of no benefit or advantage is found there will be a no buy-in of the technology at the national level. Meanwhile, the regulation, policy, 
enforcement and awareness programs will subsequently emanate when the entire process of developing and managing could be beneficial to the nations. In this figure, two gaps of BIM adoption in the Malaysia's AEC industry are predicted. Gap 1 is to ensure the acceptance of BIM at the national level. This means to say that there is a considerable attention to the benefits, competitive advantage and championship being paid to the adoption of BIM technology prior accepting it for the National Agenda (CIDB, 2013). The Gap 2; however, is to ensure the internal aspect of organisational/individual acceptance or rejection prior the implementation. Gap 2 is divided into two parts; private and public organisations. Private organisations are referring to companies run by the private entity or individuals. It encompasses businesses that are not owned by the government. Nevertheless, it may have a business associated with the government by which regulation and policies are exerted. On the other hand, public organisation means a portion of industry managed by national or state government through several respective organisations controlled by the government.

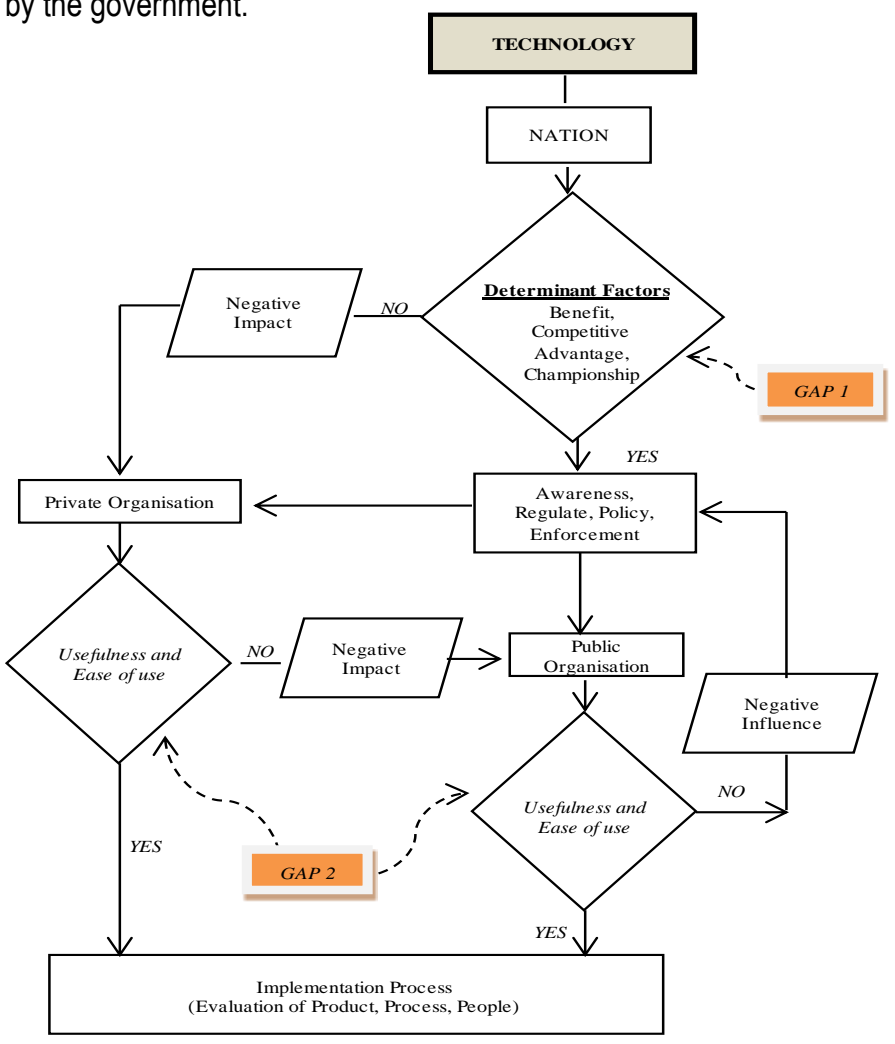

Figure 2: General process flow of new technology adoption and implementation in the AEC industry 
The usefulness and ease-of-use in implementing new technology would influence the adoption decisions at both parts (private and public organisations). In the event there is no usefulness or ease-of-use found by the private organisations, a negative influence will be asserted to the public organisations which ultimately impact the awareness program, regulation, policy and enforcement of the new technology. Gap 2 is associated with the three vital factors: BIM could increase clarity of project to all stakeholders for better decision making and reducing risk; ensuring data fidelity and continuity across project lifecycle, and providing the critical foundation to business agility. Implementing BIM on public and private projects could be done in planning, design, delivery and operational areas. In Malaysia, architects are the chief consultants in the AEC industry, but they do not seem to drive actively the BIM movements (RISM, 2013). The reason could be due to the limited access to capital, naïve and incapable in the system. Among others, RISM has initiated several BIM committees within the AEC industry, while the Public Works Department (JKR) has started to use BIM for selected projects. Nevertheless, the CIDB had formed a Technical Committee of Affordable BIM to fill the Gap 2 (CIDB, 2013). The initial initiative is through a series of workshops with the purpose to discover technical limitations in the implementation of affordable BIM with centralised storage within government agencies and product vendors in Malaysia.

\subsection{Case Study}

A case study was conducted through a preliminary workshop organised by CIDB in January 2013. It brought together five potential stakeholders: Public Private Partnership (PPP) Unit (UKAS), JARING, eMOST/ UMP, Greenwave Synergy (GWS) and CIDB eConstruct (EC). UKAS acts as the main stakeholder who will enforce the usage of BIM by contractors; JARING as the infrastructure-as-a-service (IAAS) provider; eMOST/UMP represents BIMs process adviser; while the GWS and EC represent the BIM product vendors to advise on system limitations and to develop the 'affordable BIM' platform. The purpose of this workshop is to discover the factors influencing the choice to adopt BIM in AEC industry. The outcomes of this workshop are tabulated in Table 1.

According to CIDB, there is a need to facilitate the whole AEC industries to effectively implement BIM. Despite the comprehensive understanding of the usefulness of BIM, the AEC industries need to have easy access and ease-of-use on the use of BIM for their projects. Hence, the concept of pay-per-use or periodical license was suggested that need is explored further. Meanwhile, UKAS describe that BIM could incur higher project cost since the software is expensive to purchase and implemented. For that matter, a cost is the biggest obstacles to effectively implement BIM to projects in particular among small and medium (SMEs) companies of sub-contractors and suppliers. Moreover, for a small contract value (i.e., less than RM 1 million), it is difficult for them to implement BIM for their projects. 
The concept of periodical license was suggested to support the implementation of BIM in the PPP projects.

Table 1: Factors and implementation gaps influencing the adoption of BIM in EAC industry

\begin{tabular}{|c|c|c|c|c|c|}
\hline & CIDB & UKAS & eMOST/UMP & GWS(Vendor) & EC (vendor) \\
\hline $\begin{array}{l}\text { Determining } \\
\text { factors }\end{array}$ & $\begin{array}{l}\text { Perceived usefulness } \\
\text { Ease of use } \\
\text { Championship }\end{array}$ & $\begin{array}{l}\text { Economic demand } \\
\text { People acceptance }\end{array}$ & $\begin{array}{l}\text { Technical support } \\
\text { Process change }\end{array}$ & $\begin{array}{l}\text { Product limitation } \\
\text { Product } \\
\text { interoperability }\end{array}$ & $\begin{array}{l}\text { Product limitation } \\
\text { Product } \\
\text { interoperability } \\
\end{array}$ \\
\hline $\begin{array}{l}\text { Implementation } \\
\text { Gaps }\end{array}$ & $\begin{array}{l}\text { BIMs as multi- } \\
\text { representational, } \\
\text { multi-dimensional and } \\
\text { integration of } \\
\text { information carried } \\
\text { out for project } \\
\text { implementation. }\end{array}$ & $\begin{array}{l}\text { 1. Small and } \\
\text { Medium (SMEs) } \\
\text { companies are } \\
\text { reluctant to use BIM } \\
\text { due to the expensive } \\
\text { cost of software and } \\
\text { could increase the } \\
\text { total amount of } \\
\text { project cost. } \\
\text { 2. PPP Contractor } \\
\text { transfers the cost in } \\
\text { implementing BIM } \\
\text { onto the } \\
\text { Government, } \\
\text { defeating the idea of } \\
\text { cost saving. }\end{array}$ & $\begin{array}{l}\text { 1. Specialized } \\
\text { training is required } \\
\text { for BIM among PPP } \\
\text { contractors. PPP } \\
\text { contractors are to } \\
\text { appoint BIM } \\
\text { manager to } \\
\text { coordinate the } \\
\text { training and estimate } \\
\text { the cost incurred. }\end{array}$ & $\begin{array}{l}\text { Plan to propose } \\
\text { affordable BIM } \\
\text { concept in the } \\
\text { next workshop }\end{array}$ & $\begin{array}{l}\text { Plan to propose } \\
\text { affordable BIM } \\
\text { concept in the } \\
\text { next workshop }\end{array}$ \\
\hline Suggestion & $\begin{array}{l}\text { To explore on the } \\
\text { platform of pay-per- } \\
\text { use method or } \\
\text { periodical license, } \\
\text { where SMEs able to } \\
\text { utilized during their } \\
\text { short tenancy in the } \\
\text { project. }\end{array}$ & $\begin{array}{l}\text { The concept of } \\
\text { periodical license } \\
\text { may benefit the PPP } \\
\text { contractors and } \\
\text { SMEs in which they } \\
\text { are able to } \\
\text { implement BIM } \\
\text { without incurring } \\
\text { additional cost onto } \\
\text { the project }\end{array}$ & $\begin{array}{l}\text { Specialised training } \\
\text { to be embedded } \\
\text { To propose process } \\
\text { change }\end{array}$ & $\begin{array}{l}\text { Majority of } \\
\text { software } \\
\text { companies are } \\
\text { not ready on the } \\
\text { method of pay- } \\
\text { per-use but will } \\
\text { try to explore } \\
\text { further }\end{array}$ & $\begin{array}{l}\text { To suggest a } \\
\text { special discount } \\
\text { for those who } \\
\text { want to } \\
\text { implement BIM, } \\
\text { registered through } \\
\text { CIDB portal }\end{array}$ \\
\hline Conclusion & \multicolumn{5}{|c|}{$\begin{array}{l}\text { The workshop suggested an 'affordable BIM concept' with 'pay-per-use or periodical license' method } \\
\text { to be adopted for SMEs contractors. }\end{array}$} \\
\hline
\end{tabular}

On the other hand, eMOST /UMP suggest a specialized training of BIM among PPP contractors. Through a comprehensive training, the usefulness and ease-of-use in using BIM could be discovered. Despite BIM training could incur a substantial cost for the project at the early stage, the overall cost saving could be realised in the long run. The eMOST/UMP has asserted that the cost saving throughout the project life-cycle will outweigh the additional up-front cost of implementing BIM in the construction projects. To BIM product vendors, the GWS and EC; an 'affordable BIM concept' is suggested for further discussion. The workshop has derived two important action plans: the first is to explore the possibility of providing a pilot BIM pay-per-use concept for Public Private Partnership (UKAS) projects, and the second is to investigate further the concept of 'affordable BIM' to be implemented for SMEs projects. 


\section{Conclusion}

BIM is the use of computer-generated the model to simulate the planning, design, construction and operation of a facility; a technology that allows users to create a visual simulation of a project with a digital prototype of a building before construction. The deployment of BIM in construction can make the industry more efficient, effective, flexible, and innovative. Based on the literature search and data from the preliminary workshop, it can be deduced that three (3) vital determining factors in adopting BIM at the national level are: regulation, policy \& industry standards; benefit, competitive advantage \& championship; and economic demand in the AEC industry within the perceptions of perceived usefulness and ease-of-use. To ensure the acceptance of BIM (G1) by the Government is the fundamental gap that exists at this level. Meanwhile five (5) vital determining factors captured in adopting and implementing BIM at the organisational level are: clarity of the project; fidelity and continuity across project lifecycle; business agility; training and support; and cost of implementation within the perceptions of perceived usefulness and ease-of-use. Once again the acceptance or rejection (G2) by public and private organisations is the essential gap at this level.

The workshop held by CIDB has suggested an 'affordable BIM concept' to be explored with the method of 'pay-per-use or periodical license' for SMEs contractors. The purpose is to investigate further that expensive cost of implementing BIM could give a negative impact on the ease-of-use of BIM in the AEC industry. Nevertheless, this concept will require further discussion and brainstorming in the future workshops.

\section{Acknowledgement}

The authors wish to acknowledge the contribution and assistance of the CIDB BIM Centre in providing all the relevant and necessary publications related to the topic. The author would also like to thank the BIM Centre Technical and Research Committee members for being very cooperative, attentive and supportive to the industry players and the academia in pursuing the BIM agenda in Malaysia.

\section{References}

Abukhzam, M., and Lee, A. (2010). Workforce attitude on technology adoption and diffusion. The Built \& Environment Review, 3.

Alshawi, M., Lou, E.C.W., Khosrowshahi, F., \& Underwood, J. (2010). Strategic positioning of IT in construction: The way forward. Proceedings of the International Conference on Computing in Civil and Building Engineering, Nottingham University Press.

Arayici, Y., Coates, P., Koskela, L., \& Kagioglou, M. (2012). BIM adoption and implementation for architectural practices. London: Prentice Hall. 
BTC (2005). What is technology adoption? Bridges to Technology Corporation, Ontario, Canada Retrieved from http://www.bridges-to-technology.com/page21.html

CIDB (2013). Workshop of BIM Portal and Collaboration Platform for Affordable BIM, 9th-11th January 2013, Holiday Inn Glenmarie, Shah Alam, Selangor. Kuala Lumpur: CIDB Internal Reports.

Graphisoft website (2013). Retrieved from http://www.graphisoft.com/company/about_graphisoft/

$\mathrm{Gu}, \mathrm{N}$., \& London, K. (2010). Understanding and Facilitating BIM adoption in the AEC Industry. Automation in Construction, 19, 988-999.

Davis F. D. (1989). Perceived usefulness, perceived ease of use, and user acceptance of information technologies. MIS Quarterly, 13(3), 319-340.

Hasan, H. (2012). Opening keynote address, construction, technology \& services conference (CTS), 11th \& 12th December 2012, Kuala Lumpur, Malaysia. Kuala Lumpur: CIDB Publications.

Howell, I., \& Batcheler, B. (2005). Building information modelling two years later - huge potential, some success and several limitations. USA: Newforma Publications.

Khosrowshahi, F., and Arayici, F. (2012). Roadmap for implementation of BIM in the UK Construction Industry. Engineering, Construction and Architectural Management, 19(6), 610-635

Majid, T. A., Azman, M. N. A., Zakaria S.A.S., Yahya, A. S., Zaini, S. S., Ahamad, M. S. S., \& Hanafi, M. H. (2011). Quantitative Analysis on the Level of IBS Acceptance in Malaysian Construction Industry. Journal of Engineering Science and Technology, 6(2), 179-190.

Mercer (2007). Defining quality of living, mercer human resources consulting LLC. Retrieved from http://www.imercer.com/uploads/common/pdfs/definingqualityofliving.pdf

Parente, S. L., \& Prescott, E. C. (1994). Barriers to technology adoption and development. The Journal of Political Economy, 102(2), 298-321.

Pemandu (2011). Economic Transformation Plan- The ROADMAP for Malaysia: A special report, performance management and delivery unit (PEMANDU)

RISM (2013). Sub-Committee meeting, 19th January 2013, RISM Headquarters, Petaling Jaya. Selangor: RISM BIM Sub-Committee Publications.

Shuratman, Z. (2012). Building Information Modelling in Local Construction Industry. Ph.D. Thesis, University Technology Malaysia

Suebsin, C., \& Gerdsri, N. (2009). Key factors driving the success of technology adoption: Case examples of ERP Adoption, PICMET 2009 Proceedings, August 2-6, Portland. USA: Oregon.

Teng, J. T. C., \& Nelson, A. (1996) The Influence of Organisational Factors on CASE technology adoption. Journal of Information Technology Management, 7

Weygant, R. S. (2011). BIM content development, standards, strategies, and best practices, construction specification institute. 
Wong, A. K. D., Wong, F. K. W., \& Nadeem, A. (2009). Comparative roles of major stakeholders for the implementation of BIM in various countries. Proceedings of the International Conference on Changing Roles: New Roles, New Challenges, Noordwijk Aan Zee, The Netherlands, 5-9 October.

Wong, A. K. D., Wong, F. K. W., \& Nadeem, A. (2011). Government Roles in Implementing Building Information Modelling Systems: Comparison between Hong Kong and the United States. Construction Innovation, Information, Process, Management, 11 